\title{
Characteristics, Nutritional Status, and Lipid Profile of Dyslipidemia Patients with Mediterranean Diet
}

\author{
Dewi Ratih Handayani, Iis Inayati Rakhmat \\ Department of Biochemistry, Faculty of Medicine \\ University of Jenderal Achmad Yani \\ Cimahi, Indonesia
}

\author{
Endry Septiadi* \\ Department of Nutrition, Faculty of Medicine \\ University of Jenderal Achmad Yani \\ Cimahi, Indonesia \\ *endry.septiadi@lecture.unjani.ac.id
}

\author{
M. Arasy Faradina, Reza Fadhil Nugraha, Achmad Hero Prawira, Rifal Aldi Anugrah \\ General Medicine Study Program, Faculty of Medicine \\ University of Jenderal Achmad Yani \\ Cimahi, Indonesia
}

\begin{abstract}
Dyslipidemia is a lipid metabolism disorder with an imbalance of lipid fraction in plasma, including increase in total cholesterol, LDL, TGA, and decrease in HDL. Changes in lipid profile levels can be influenced by several factors, namely diet, physical activity, lifestyle, age, sex, and genetics. Poor diet, such as consuming foods that contain excessive fat can cause abnormal lipid profile. The Mediterranean diet is a recommended diet for people with dyslipidemia because it contains ingredients such as unsaturated fatty acids (MUFA and PUFA), high antioxidants, and low glycemic index that improve nutritional status and lipid profile levels. This study aims to determine the characteristics, nutritional status and lipid profile levels of dyslipidemia patients with a Mediterranean diet. This research is descriptive study with cross-sectional approach and the sample was 37 dyslipidemia patients on Mediterranean Diet collected by consecutive sampling. Nutrional status examination involved BMI which mostly the patients had obesity I; waist circumference which mostly the female patients had $\geq 80 \mathrm{~cm}$ and male patients had $\leq 90 \mathrm{~cm}$; and lipid profile which the average level of cholesterol total $188,84 \mathrm{mg} / \mathrm{dL}$, HDL $41,00 \mathrm{mg} / \mathrm{dL}$, LDL $130,43 \mathrm{mg} / \mathrm{dL}$, and TGA $117,41 \mathrm{mg} / \mathrm{dL}$. Mediterranean Diet effects had been proved showing the normal average level of total cholesterol, HDL, and TGA meanwhile LDL level and nutritional status were abnormal.
\end{abstract}

Keywords-dyslipidemia, mediterranean diet, nutritional status, lipid profile

\section{INTRODUCTION}

Dyslipidemia is a lipid metabolism disorder with an imbalance in the lipid fraction in plasma [1]. According to WHO data, in 2008 the global prevalence of dyslipidemia in adult patients was $39 \%$ [2]. $200 \mathrm{mg} / \mathrm{dl}$ is $35.9 \%, 15.9 \%$ of the population has very high LDL levels $(\geq 190 \mathrm{mg} / \mathrm{dl}$ ) and $22.9 \%$ of the population has HDL levels <40 mg / dl. Meanwhile, $11.9 \%$ of the population has a very high TGA level, namely $\geq 500 \mathrm{mg} / \mathrm{dl}$ [3]. Risk factors for dyslipidemia include age, gender, obesity, diet, waist circumference, and physical activity [4] dyslipidemia. Men aged $\geq 40$ years and female aged $\geq 50$ years or having menopause are risk factors for dyslipidemia. This is due to decreased organ function and metabolic rate which causes a decrease in the activity of LDL receptors so that the fat in the body will increase and lead to high levels of total cholesterol. Gender is also very influential on the occurrence of dyslipidemia. Men are more at risk of developing dyslipidemia because men have the hormone testosterone, which accelerates atherosclerosis. Apart from age and gender, diet and physical activity greatly affect the levels of the lipid profile, making it susceptible to dyslipidemia $[5,6]$.

Nutritional status is the state of the body as a result of food consumption. One way to measure nutritional status is the body mass index (BMI). One of the causes of increased BMI is a high-fat diet [7].

The non-pharmacotherapy of dyslipidemia includes lifestyle changes including physical activity, medical nutritional therapy, weight loss and smoking cessation, while for pharmacotherapy, lipid-lowering drugs are given [8-10].

The Mediterranean diet is a traditional diet that has characteristics, namely the consumption of fruits, vegetables, nuts, adequate consumption of fish and meat. poultry, low dairy products, low red meat, low processed meat, low sweet foods, moderate consumption of wine and cereals as staple foods [11-14].

Non-pharmacotherapy management is starting to be widely used by the wider community and growing rapidly, one of which is by doing the Mediterranean diet. The Mediterranean diet has gained popularity over the last few decades because of its favorable taste and its beneficial effects on health. The levels of antioxidants and unsaturated fatty acids (PUFA) in the 
Mediternia diet are very good for patients with dyslipidemia because they can prevent damage to the endothelium of blood vessels so that they can improve the patient's quality of life [13].

In Indonesia, research on the Mediterranean diet is relatively small. The types of disease, diet, healthy lifestyle, and nutritional status of Indonesians are different from those of Mediterranean people. especially with the type and composition of food in Indonesia which is different from the type and composition of food in the Mediterranean region. This is the reason for researchers to continue this research in Indonesia.

\section{MATERIALS AND METHODS}

The research design used was descriptive to determine the characteristics, nutritional status, and lipid profile levels in dyslipidemic patients with a Mediterranean diet. Retrieval of data by cross-sectional. Subjects who did a Mediterranean diet were identified using a questionnaire, namely the Mediterranean Adherence Screener (MEDAS). The sampling method was carried out using consecutive sampling technique.

The population in this study were dyslipidemic patients who were undergoing a Mediterranean diet in a clinic that has Prolanis in the Bandung area in December 2019. In this study, a sample of 37 patients was obtained.

The tools used in the enzymatic lipid profile examination are spectrophotometer, $10 \mu \mathrm{l}$ and $1000 \mu \mathrm{l}$ micropipettes, test tubes, test tube racks, blue tip, yellow tip, and tissue. The tools used to measure BMI (anthropometry) are beam balance, microtoise, measuring tape, and fluff or markers. The examination materials used to measure the lipid profile were the subject's blood serum, standard solution, cholesterol reagent solution, cholesterol standard, HDL precipitating reagent, TGA standard, TGA reagent, working reagent, and aquadest. This study began by looking for the results of lipid profiles based on medical records, taking data on the Mediterranean diet and patient characteristics through questionnaires based on age, sex, and education, patient preparation, anthropometric measurements by measuring body weight and height, intravenous blood sampling, and measurement of the lipid profile of total cholesterol, HDL, LDL, and TGA.

The Mediterranean diet scoring uses the validated Mediterranean Adherence Screener (MEDAS) with 14 units of dietary score. A score of 1 if the response is appropriate (yes) and a score of 0 if the response is not suitable (no). Scores with a range of 9 or more have a favorable advantage and are defined as the Mediterranean diet [15].

Data processing was performed using the SPSS statistical application. The collected data were processed and analyzed descriptively.

\section{RESULTS}

\section{A. Age Characteristics}

Based on Table 1 the results of the study obtained that the average age of the patients was 55.32 years. The youngest age of the patient was 33 years and the oldest age was 78 years. See table 1 below.

TABLE I. AGE OF DyslipidEMIC PATIENTS ON A MEDITERRANEAN DIET

\begin{tabular}{|l|c|l|c|l|l|}
\hline & \multicolumn{5}{|c|}{ Age } \\
\cline { 2 - 6 } & Mean & Median & SD & Min-max & $(95 \%$ CI $)$ \\
\hline $\begin{array}{l}\text { Mediterranean } \\
\text { diet }\end{array}$ & 55.32 & 55.00 & 9.27 & $33-78$ & $\begin{array}{l}52.23 \\
58.42\end{array}$ \\
\hline
\end{tabular}

The results of this study occurred because the average population in the Prolanis community of patients who had entered the age of more than 33 years. Based on theory, age is very influential in increasing the lipid profile, especially those over 40 years of age. In patients with dyslipidemia, men aged $\geq 40$ years and female aged $\geq 50$ years or who have menopause are risk factors for this disease. Age will affect LDL receptors in cells in the form of decreased LDL receptor activity resulting in transport disruption resulting in high levels of LDL in the blood $[16,17]$.

Based on the literature by Karam et al, 2019, it is known that in Mallorca, Spain, the number of people who consume the Mediterranean diet is seen from the intake of unsaturated fatty acids, which is mostly followed by younger participants (aged $<67$ years) than older participants (aged $\geq 67$ years) [18].

\section{B. Gender Characteristics}

Based on Table 2, gender in this study shows that most of the patients were female, as many as 25 people, while men were 12 people.

TABLE II. GENDER AND LEVEL OF EDUCATION

\begin{tabular}{|l|l|l|}
\hline \multicolumn{1}{|c|}{ Characteristics } & \multicolumn{1}{|c|}{ N } & \% \\
\hline Gender & & \\
\hline Male & 12 & 32.4 \\
\hline Female & 25 & 67.6 \\
\hline Level of Education & & \\
Elementery School & 10 & 27 \\
Junior High School & 9 & 24.3 \\
Senior High School & 15 & 40.5 \\
College & 3 & 8.1 \\
\hline
\end{tabular}

Total sample: $\mathrm{N}=37$

The results of this study can occur because in one population in the Prolanis community most of them are female. Based on the literature conducted by Karam et al, 2019 the number of people who consume the Mediterranean diet as seen from their intake of unsaturated fats, number of sexes who consumed the Mediterranean diet were female [18,19].

The results showed that the number of dyslipidemia sufferers with a high risk incidence occurred in men. 
Men have the hormone testosterone, which accelerates atherosclerosis. However, after menopause, the incidence of dyslipidemia in female tends to increase and is comparable to that of men. At menopause the womaleexperiences a deterioration in lipid profiles with the transition to dyslipidemia and increases the risk of atherogenic formation $[5,20]$.

\section{Level of Education}

Research conducted by Li K, 2016 and Ramirez, 2006 in Ireland and Mexico found that high intake of unsaturated fatty acids, especially good MUFA intake in patients with a high level of education [19,21]. Education level is related to an increase in the level of nutritional knowledge due to awareness nutrition and health improve with education levels, resulting in healthier eating habits and patterns [22]. A similar study conducted by Tabbakh, 2016 found that greater nutritional knowledge was associated with higher food quality and nutritional knowledge demonstrated this effect through increased attitudes towards healthy eating [23].

A good knowledge level education can motivate dyslipidemia patients with appropriate educational methods so as to achieve the target. In this study, the average patient education is high school (SMA). The patients in this study were already familiar with the concept of the Mediterranean diet. This is because every patient has received socialization and counseling about the Mediterranean diet by Prolanis which is held every month so that patients gain knowledge of the Mediterranean diet.

\section{Nutritional Status Based on BMI}

TABLE III. NutritioAl Status BASED ON BMi AND WAIST SizE

\begin{tabular}{|c|l|l|}
\hline \multicolumn{1}{|c|}{ Characteristics } & \multicolumn{1}{|c|}{ N } & \multicolumn{1}{|c|}{$\%$} \\
\hline BMI & & 2.7 \\
\hline$<18,5$ Underweight & 1 & 29.7 \\
\hline $18,5-22,9=$ Normal BB & 11 & 16.2 \\
\hline $23-24,9=$ Overweight & 6 & 37.8 \\
\hline $25-29,9=$ Obesity I & 14 & 13.5 \\
\hline$>30 \quad=$ Obesity II & 5 & 16 \\
\hline Waist Size of Female & & 84 \\
Female $\leq 80 \mathrm{~cm}$ & 4 & \\
Female $>80 \mathrm{~cm}$ & 21 & 58.3 \\
Waist Size of Male & 7 & 41.6 \\
Male $\leq 90 \mathrm{~cm}$ & 5 & \\
Male $>90 \mathrm{~cm}$ & \multicolumn{2}{|}{} \\
\hline
\end{tabular}

Total sample: $\mathrm{N}=37$

Based on Table 3, the body mass index of the most research patients was in the category group BMI obesity I with a range of 25-29.9, namely 14 patients or with a percentage of $37.8 \%$.

Increasing saturated fat intake can result in weight gain. This is due to the buildup of TGA in the adipose tissue, which can cause excess body weight. The Mediterranean diet can reduce the risk of obesity because the Mediterranean diet contains unsaturated fats that can lead to weight loss [24,25]. Several components of the Mediterranean diet such as high grain content, dietary fiber, and MUFA have been shown to affect the distribution of adipose tissue.

The results of this study still found patients who were overweight, obese I and II even though they had been doing a Mediterranean diet for 1 month. Based on the literature, there are 2 studies conducted at different times, such as a study conducted by Bedard et al., 2012 where there was a significant small reduction in waist circumference in obese individuals who consumed a Mediterranean diet for 1 month. The changes seen after BMI measurements before and after being given the Mediterranean diet ranged from -0.38 (SEM 0.07) kg / m2.26 In contrast to research conducted by Fernandez, 2012, who carried out a Mediterranean diet for 3 months. These results obtained a weight loss of approximately $9 \mathrm{~kg}$ and a BMI of 4 $\mathrm{kg} / \mathrm{m} 2$. It is based on restricting $40 \%$ of the usual energy intake $(500 \mathrm{kcal} /$ day; where $1 \mathrm{kcal}=4,168 \mathrm{~kJ})$ for weight loss where $20 \%$ is given in the first month and $10 \%$ in the following month up to a 3-month period. This calorie restriction will lead to weight loss, thereby reducing the risk of obesity $[26,27]$.

Based on waist size, it can be seen that there are 4 female patients with a waist circumference of $\leq 80 \mathrm{~cm}$ and the most female patients with a waist circumference $>80 \mathrm{~cm}$, amounting to 21 people with a percentage of $16 \%$ and $84 \%$ respectively. The most male patients with a waist circumference $\leq 90 \mathrm{~cm}$, amounting to 7 people with a percentage of $58.3 \%$ and male patients with a waist circumference $>90 \mathrm{~cm}$ as many as 5 people with a percentage of $41.6 \%$.

A high-fat diet can lead to fat accumulation in this case, namely TGA in adipose tissue, especially in the abdominal area, causing central obesity and measured on waist circumference examination. The higher the waist circumference the more risk of cardiovascular disease. $[25,28,29]$.

In this study, there were still patients with an excess waist circumference, especially in female, even though these patients had been on a Mediterranean diet for 1 month. The length of time consuming a Mediterranean diet and inadequate physical activity have a profound effect on waist circumference. Research conducted by Bedard, 2012 with a time of 1 month is enough to give effect to changes in waist circumference. It's just that it takes longer for maximum changes. The ideal time according to research conducted by Fernandez, 2012 is three months because a decrease in calories per day ( $500 \mathrm{kcal} /$ day) and physical activity can reduce waist circumference by approximately $7 \mathrm{~cm}$ in 3 months of consuming the Mediterranean diet and physical activity [30-32].

\section{E. Levels of Lipid Profiles in Dyslipidemic Patients}

Based on Table 4, the checked lipid profile shows that the average total cholesterol, HDL, and TGA levels are within normal limits, but the LDL level shows high results. 
TABLE IV. LIPID PROFILE

\begin{tabular}{|l|l|l|l|l|}
\hline \multicolumn{1}{|c|}{ Variable } & \multicolumn{1}{c|}{$\begin{array}{c}\text { Mean } \\
(\mathbf{m g} / \mathbf{d l})\end{array}$} & $\begin{array}{l}\text { Min- } \\
\mathbf{m a x}\end{array}$ & \multicolumn{1}{|c|}{ SD } & \multicolumn{1}{c|}{$(\mathbf{9 5 \%}$ CI) } \\
\hline $\begin{array}{l}\text { Total } \\
\text { Cholesterol }\end{array}$ & 188.84 & $\begin{array}{l}144- \\
285\end{array}$ & 34,96 & $177,18-200,50$ \\
\hline LDL & 130.43 & $\begin{array}{l}70- \\
222\end{array}$ & 32,60 & $119,56-141,30$ \\
\hline HDL & 41.00 & $25-70$ & 10,39 & $37,54-44,46$ \\
\hline Triglycerides & 117.41 & $\begin{array}{l}59- \\
279\end{array}$ & 42,87 & $103,11-131,70$ \\
\hline
\end{tabular}

The Mediterranean diet contains content such as unsaturated fatty acids (PUFA and MUFA), high antioxidants, and a low glycemic index that can improve lipid profile levels [8,30,31]. Research conducted by Estruch, 2015 found a decrease in TGA levels after was given a Mediterranean diet [32]. The mechanism underlying the decrease in TGA concentrations is due to the effect of omega 3 fatty acids (PUFA) obtained when consuming fish and olive oil. Omega 3 fatty acids this can inhibit the secretion of hepatic VLDL so that the TGA concentration will be reduced. This is consistent with this study, which can be seen from the average TGA level in patients on a Mediterranean diet, which is $<150 \mathrm{mg} / \mathrm{dl}$ [33,34].

On the Mediterranean diet it is advisable to consume complex carbohydrates and does not recommend consuming refined carbohydrates. Refined carbohydrates tend to increase visceral adiposity, decrease insulin sensitivity, and stimulate de novo hepatic lipogenesis, which results in decreased HDL levels. Conversely, the beneficial effect of the Mediterranean diet on HDL could be due to the higher consumption of olive oil. Olive oil has been associated with higher levels of trienoic prostaglandins and results in improved plasma lipid profiles, such as an increase in serum HDL. This is in accordance with this study which can be seen from the average HDL levels in patients who are doing a Mediterranean diet, which is $>40 \mathrm{mg} /$ dl [35].

According to Tosti et al., 2018 the mechanism explaining lower plasma cholesterol levels in individuals consuming the Mediterranean diet is because the Mediterranean diet is rich in whole grains, nuts and dried fruits providing at least $14 \mathrm{~g}$ of vegetable fiber for every $1,000 \mathrm{kcal}$ per day. more than double the normal daily consumption. The water-soluble fiber reduces the absorption of cholesterol and bile acids in the small intestine. Additionally, low-glycemic fiber-rich foods have been shown to decrease insulin production and increase levels of short-chain fatty acids produced by fiber fermentation so both have been shown to inhibit cholesterol synthesis. High intake of phytosterols from nuts, seeds, whole grains, vegetables, and fruits can also play an important role in lowering plasma cholesterol levels to compete with cholesterol absorption in the intestine [36]. This is in accordance with this study which It can be seen from the average total cholesterol level in patients who do the Mediterranean diet, which is $<200$ $\mathrm{mg} / \mathrm{dl}[33]$.

Based on research conducted by Damasceno, 2013, it was found that the results of decreasing LDL levels after doing the
Mediterranean diet were accompanied by good physical activity. When physical activity can reduce TGA levels, which causes VLDL synthesis to decrease, causing the lipolysis process of VLDL which results in low LDL in the blood circulation. This fact is different from this study because in this study the patient's physical activity was not known, however, from the results obtained, LDL levels in patients who did a Mediterranean diet tended to be high even though they had been doing a Mediterranean diet for 1 month. In addition, the cost factor makes it less than optimal for patients to consume olive oil [37].

The factor of less than optimal consumption of olive oil and the patient's physical activity that was not known to cause the improvement of the lipid profile was not optimal, especially it can be seen from the average LDL level. Purchasing olive oil is a little more expensive than other oils. Olive oil is considered a pillar of the Mediterranean diet because it contains monounsaturated fatty acids (MUFA and PUFA) which can suppress major risk factors for cardiovascular disease, such as lipid profile, blood pressure, glucose metabolism and antithrombotic profile [13].

In this study, the time of consuming the Mediterranean diet for 1 month with different conditions for each patient can describe the results of the examination of the lipid profile based on total cholesterol, HDL, and TGA with a good average, while the LDL shows an average outside the normal limit. Research conducted by Be'dard, 2012, where the consumption of the Mediterranean diet for 1 month can have an effect on improving lipid profile levels.26 In contrast to research conducted by Fernandez, 2012 where giving the Mediterranean diet for 3 months will improve lipid profile levels, especially LDL. Normal LDL levels can prevent atherosclerosis. This mechanism occurs because there is an increase in weekly adaptation to NO obtained from consuming MUFA and PUFA, antioxidants from nuts and fruits, as well as good physical activity so that NO activity is reduced. It can repair endothelial cells and repair neovascularization after ischemia, thus preventing cardiovascular disease [27,30-32].

\section{DISCUSSION}

The Mediterranean diet contains omega 3 acids (PUFAs). PUFA are found in fish oil. The mechanisms underlying the beneficial effects of fish oil on cardiovascular disease include improvement of lipid profiles and lowering blood pressure through reduced inflammation, oxidation reactions, and coagulation. The effect of monounsaturated fatty acids (MUFAs) on markers for cardiovascular disease such as cholesterol suggests that intake of monounsaturated fatty acids increases lipid levels, especially HDL cholesterol $[8,30]$.

A carbohydrate-rich diet can decrease HDL concentrations and increase TGA concentrations in the blood. The Mediterranean diet has a low carbohydrate content because the consumption of carbohydrates in the Mediterranean diet is less than the carbohydrate needs of a normal person $(<60 \%$ of total calories), thus preventing a decrease in HDL and an increase in 
TGA. This is based on the fact that consumption of lots of carbohydrates will increase TGA. The increase in TGA causes HDL catabolism to also increase so that HDL levels in the blood decrease [30].

The benefits of fruits and vegetables in the Mediterranean diet may lie in reducing the total calorie load according to the many micronutrients supplied. the antioxidant properties of fruits and vegetables and increased flavonol intake affect nitric oxide (NO) levels and can also lead to concurrent weight loss [30].

Many data show a beneficial effect of whole grain consumption on cardiovascular disease morbidity and mortality. The AHA guidelines suggest that a diet high in fiber, such as whole grains, wheat, and barley, reduces cardiovascular disease morbidity and mortality through reduced fat [31].

The mechanisms for the benefits of whole grains in cardiovascular disease include reduction of inflammation, oxidation reactions, lipid profiles, and blood pressure. Consumption of whole grains improves glucose metabolism, reduces body weight and improves antioxidant capabilities. A high-fiber, pure grain diet may inhibit the absorption of fats, simple carbohydrates, or toxins $[8,30,32]$.

\section{CONCLUSION}

The effect of the Mediterranean diet on dyslipidemic patients has been shown to show normal mean levels of total cholesterol, HDL, and TGA, while LDL levels and meanwhile nutritional status show abnormal means.

\section{ACKNOWLEDGMENT}

In preparing this scientific article, it is inseparable from assistance, advice, and guidance from various parties, therefore on this occasion, the author would like to thank the Dean and staff of the Faculty of Medicine, General Achmad Yani University, research staff who always assist in examination activities, All dyslipidemia patients in the clinical prolanis community where the research was willing to be the subject of research, parents, and friends who always informed me in completing this scientific article.

\section{REFERENCES}

[1] National Cholesterol Education Program (NCEP), Detection, evaluation, and treatment of high blood cholesterol in adult (Adult tratment panel III). Final report. National Institues of Health-NIH Publication. 2002.

[2] World Health Organization (WHO), "Epidemiological situation," [Online]. Retrieved from https://www.who.int/leishmaniasis/burden/en/ ) 2016, accessed on January 10th 2019.

[3] Badan Penelitian Dan Pengembangan Kesehatan Kementerian Kesehatan RI, Riset Kesehatan Dasar. RISKESDAS. Jakarta. 2013.

[4] L. Kustiyah, W.M. Utami, and D. Mira, "Hubungan Asupan Serat Dengan Status Gizi Dan Profil Lipid Darah Pada Orang Dewasa Dislipidemia," J Gizi dan Pangan, vol. 8, no. 3, pp. 193-200, 2013.
[5] P.M. Arsana, R. Rosandi, A. Manaf, A.A.G. Budhiarta, H.W. Permana, and K. Sucipta, Panduan Pengelolaan Dislipidemia Indonesia. PERKENI. 2015, 1:8.

[6] Nurftriani, Pristianty L, and I.R. Hidayati, "Analisis faktor-faktor perilaku yang berpengaruh terhadap ketepatan penggunaan obat dislipidemia." Jurnal Farmasi Komunitas, vol. 2, pp. 229-35, 2015.

[7] A. Hartono, Terapi Gizi Dan Diet Rumah Sakit. Edisi 2. Jakarta: EGC. 2013, pp. 93-94.

[8] Z. Labibah and D.I. Anggraini, "Diet Mediterania dan Manfaatnya terhadap Kesehatan Jantung dan Kardiovaskula," J Majoriity, vol. 5, pp. $1-3,2016$.

[9] J. Haas, L. Bellows, S. Ganster, and R. Moore, The mediterranean diet Colorado State University, Fact Sheet No. 9.386, 2014.

[10] A. Sanchez, A. Mejia, J. Sanchez, E. Runte, S. Brown-Fraser, and R.L. Bivens, "Diets with customary levels of fat from plant origin may reverse coronary artery disease," Med Hypotheses, pp. 103-5, 2019.

[11] V. Tosti, B. Bertozzi, and L. Fontana, "Health Benefits of the Mediterranean Diet: Metabolic and Molecular Mechanisms." Biological Sciences, vol. 73, pp. 318-326, 2017.

[12] Mediterranean Food Alliance (MFA), Make Each Day Mediterranea. MFA. Boston. 2012

[13] R. Estruch, E. Ros, J.S. Salvado, M.I. Covas, D. Corella, and F. Aros, "Primary Prevention of Cardiovascular Disease with a Mediterranean Diet.” N Engl J Med., vol. 368, pp. 2441-2, 2013.

[14] A. Be'dard, L. Corneau, M.C. Vohl, S. Dodin, and S. Lemieux, "Effect of the Mediterranean diet on lipid and lipoprotein profile: is it influenced by the family history of dyslipidemia?" J Nutrigenet Nutrigenomics, vol. 7, pp. 177-87, 2014.

[15] A. Papadaki, L. Johnson, Z. Toumpakari, C. England, M. Rai, and S. Toms, "Validation of the English version of the 14-item mediterranean diet adherence screener of the PREDIMED study, in people at high cardiovascular risk in the UK." Nutrients, vol. 10, 2018.

[16] G.S. Alzahrani, S.M. Aljehani, and J.J. Al-Johani, "Risk Factors of Dyslipidemia among Saudi Population, 2017," Egypt J Hosp Med., vol. 71, no. 1, pp. 2262-5, 2018.

[17] B.A.P. Phan and P.P. Toth, "Dyslipidemia in female: Etiology and management," Int J Females Health, vol. 6, no. 1, pp. 185-94, 2014.

[18] J. Karam, M. del M Bibiloni, A. Pons, and J.A. Tur, "Total fat and fatty acid intakes and food sources in Mediterranean older adults requires education to improve health," Nutr Res., vol. 73, pp. 67-74, 2020.

[19] K. Li, B.A. McNulty, A.M. Tiernery, N.F.C. Devlin, T. Joyce, and J.C. Leite, "Dietary fat intakes in Irish adults in 2011: How much has changed in 10 years?" Br J Nutr., vol. 115, pp. 1798-809, 2016.

[20] B. Budimale, R. Sihombing, and P. Pradina, "Hubungan Dislipidemia, Hipertensi Dan Diabetes Melitus Dengan Kejadian Infark Miokard Akut," J Kesehat Masy Andalas, vol. 10, p. 32, 2017..

[21] I. Ramírez-Silva, S. Villalpando, J.E. Moreno-Saracho, and D. BernalMedina, "Fatty acids intake in the Mexican population. Results of the National Nutrition Survey 2006," Nutr Metab., vol. 8, no. 33, p. 22, 2011.

[22] S. Akkartal and C. Gezer, "Is Nutrition Knowledge Related to Diet Quality and Obesity?" Ecol Food Nutr., pp. 1-11, 2019.

[23] T. Tabbakh and J.H. Freeland-Graves, "The home environment: A mediator of nutrition knowledge and diet quality in adolescents." Appetite, vol. 105, pp. 46-52, 2016.

[24] G. Buckland, A. Bach, and L. Serra-Majem, "Obesity and the Mediterranean diet: A systematic review of observational and intervention studies." Obes Rev., vol. 9, pp. 582-93, 2008.

[25] S. D'innocenzo, C. Biagi, and M. Lanari, "Obesity and the mediterranean diet: A review of evidence of the role and sustainability of the mediterranean diet." Nutrients, vol. 11, 2019.

[26] A. Bédard, S. Dodin, L. Corneau, and S. Lemieux, "The impact of abdominal obesity status on cardiovascular response to the mediterranean diet." J Obes., pp. 1-9, 2012. 
[27] J.M. Fernández, D. Rosado-Álvarez, M.E. Da Silva Grigoletto, O.A. Rangel-Zúñiga, L.L. Landaeta-Díaz, and J. Caballero-Villarraso, "Moderate-to-high-intensity training and a hypocaloric Mediterranean diet enhance endothelial progenitor cells and fitness in subjects with the metabolic syndrome." Clin Sci., vol. 123, pp. 361-73, 2012.

[28] G. Buckland, A. Bach, and L. Serra-Majem, "Obesity and the Mediterranean diet: A systematic review of observational and intervention studies.' Obes Rev., vol. 9, pp. 582-93, 2008.

[29] C.L. Bendall, H.L. Mayr, R.S. Opie, M. Bes-Rastrollo, C. Itsiopoulos, and C.J. Thomas, "Central obesity and the Mediterranean diet: A systematic review of intervention trials." Crit Rev Food Sci Nutr., vol. 58, pp. 3070-84, 2018.

[30] R.J. Widmer, A.J. Flammer, L.O. Lermale, and A. Lermale, "The Mediterranean diet, its components, and cardiovascular disease.” Am J Med., vol. 128, pp. 229-38, 2015.

[31] American College Of Cardiology/ American Heart Association (ACC/AHH), "Guidline One The Primary Prevention Of Cardiovascular Disease: A Report Of The American College Of Cardiology/American Heart Association Task Force On Clinical Practice Guidelines.” J Am Coll Cardiol, pp. 4-17, 2019.
[32] R. Estruch and M. Camafort, "The mediterranean diet and plasma lipid profile." Rev Esp Cardiol., vol. 68, pp. 279-81, 2015.

[33] American Association of Clinical Endocrinologists and American College of Endocrinology (AACE), Guidelines for Management of Dyslipidemia and Prevention of Cardiovascular Disease - Executive Summary. AACE. United States, 2017.

[34] W.S. Harris and D. Bulchandani, "Why do omega-3 fatty acids lower serum triglycerides?" Curr Opin Lipidol, vol. 17, pp. 387-93, 2006.

[35] J.L. Peñalvo, B. Oliva, M. Sotos-Prieto, I. Uzhova, B. Moreno-Franco, and M. León-Latre, "Greater Adherence to a Mediterranean Dietary Pattern Is Associated With Improved Plasma Lipid Profile: the Aragon Health Workers Study Cohort.” Rev Española Cardiol (English Ed), vol. 68, pp. 290-7, 2015.

[36] V. Tosti, B. Bertozzi, and L. Fontana, "Health Benefits of the Mediterranean Diet: Metabolic and Molecular Mechanisms," Journals Gerontol - Ser A Biol Sci Med Sci., vol. 73, pp. 318-26, 2018.

[37] N.R.T. Damasceno, A. Sala-Vila, M. Cofán, A.M. Pérez-Heras, M. Fitó, and V. Ruiz-Gutiérrez, "Mediterranean diet supplemented with nuts reduces waist circumference and shifts lipoprotein subfractions to a less atherogenic pattern in subjects at high cardiovascular risk." Atherosclerosis, vol. 230, pp. 347-5, 2013 